\title{
Plasma zinc level during acute gastroenteritis
}

\author{
Nicoleta Negruț \\ From The 10th Edition of the Scientific Days of the National Institute for Infectious Diseases "Prof Dr Matei \\ Bals" \\ Bucharest, Romania. 15-17 October 2014
}

\section{Background}

Gastroenteritis may result in loss of zinc by feces, decreased tissue levels of zinc and negative zinc balance in children.

\section{Methods}

The first aim of the study was to determine the plasma zinc level on admission in the hospital and 10 days after the recovery from acute gastroenteritis, in children aged 03 years, from the region of Bihor, Romania. Second aim of the study was to analysis the plasma zinc level according to the etiology of gastroenteritis. Zinc sulfate (10-20 mg daily, according to age) was given to the patients in the study group, for 10 days. The colorimetric method with Br-PAPS final point (CV\% 0.98\%-4.64\%) was used for the determination of the zinc level. The program IBM SPSS statistics version 22 was used for analysis of the data.

\section{Results}

During three years (2009-2011), 103 children with acute gastroenteritis were enrolled in the study. The mean plasma zinc level in the $10^{\text {th }}$ day versus day 0 , increased in the study group $(\mathrm{n}=53)(14.59 \pm 2.55 \mu \mathrm{mol} / \mathrm{L}$ versus 15.66 $\pm 3.98 \mu \mathrm{mol} / \mathrm{L}, \mathrm{p}=0.049$, Student's test) and decreased in the control group $(\mathrm{n}=50)(15.08 \pm 3.28 \mu \mathrm{mol} / \mathrm{L}$ versus $13.59 \pm 3.02 \mu \mathrm{mol} / \mathrm{L}, \mathrm{p}=0.041$, Student's test). In the day 0 , there were no significant differences between plasma zinc level in children with bacterial gastroenteritis compared with viral gastroenteritis $(13.97 \pm 2.52 \mu \mathrm{mol} / \mathrm{L}$ versus $14.08 \pm 2.19 \mu \mathrm{mol} / \mathrm{L}, \mathrm{p}=0.911$, Student's $\mathrm{t}$ test).

\section{Conclusion}

Plasma zinc level decreased after 10 days of acute gastroenteritis. The etiologic agent of diarrhea did not influence the plasma level of zinc.

Correspondence: Inm_n10@yahoo.com

Faculty of Medicine and Pharmacy, University of Oradea, Romania
Acknowledgement

This study was supported by own sources.

Published: 15 October 2014

doi:10.1186/1471-2334-14-S7-P53

Cite this article as: Negruț: Plasma zinc level during acute gastroenteritis. BMC Infectious Diseases 2014 14(Suppl 7):P53. and take full advantage of:

- Convenient online submission

- Thorough peer review

- No space constraints or color figure charges

- Immediate publication on acceptance

- Inclusion in PubMed, CAS, Scopus and Google Scholar

- Research which is freely available for redistribution 